\title{
New-Build Gentrification: Its Histories, Trajectories, and Critical Geographies ${ }^{1}$
}

\author{
Mark Davidson ${ }^{1}$ and Loretta Lees ${ }^{2}$ \\ ${ }^{1}$ Graduate School of Geography, Clark University, Worcester, Massachusetts, USA \\ ${ }^{2}$ Cities Research Group, Department of Geography, King's College London, UK
}

\section{ABSTRACT}

New-build gentrification has been the subject of renewed attention of late. The impetus was Lambert and Boddy, who asserted that inner-city new-build developments in British city centres should not be viewed as a form of gentrification. While the term has long been generally accepted, Lambert and Boddy, and, more recently, Boddy, argue that the demographic transformations stimulated by city centre new-build developments are relatively innocuous. They do not cause population displacement, and are not associated with the rent-hike and eviction processes of gentrification proper. Indeed, within a move to rethink the workings and consequences of gentrification more generally (e.g. Butler), there has been a new questioning of whether this, or any, contemporary form of gentrification produces significant displacement concerns. In this paper, we address these new debates. We begin by tracing the histories of new-build gentrification, highlighting its long-standing presence, and then we move on to look at its trajectories, focusing our lens on London to demonstrate the diversity and complexity of this process in just one city. We outline the presence of displacement - both direct and indirect - as a complex and nuanced process (not just a spatial moment), but one that has nevertheless had a real-life impact on real people. Copyright $(C) 2009$ John Wiley \& Sons, Ltd.

*Correspondence to: Mark Davidson, Graduate School of Geography, Clark University, 950 Main Street, Worcester, MA 01610, USA. E-mail: MDavidson@clarku.edu
Received 14 October 2008; revised 18 March 2009; accepted 11 May 2009

Key words: new-build gentrification, public policy, population displacement, London

\section{INTRODUCTION}

W hen luxury apartment complexes or townhouses are built on reclaimed brownfield land, does it count as gentrification? These are not old houses, and some argue there is no displacement of a low-income community. When public housing is knocked down to make way for new-build middle-class homes in so-called 'mixed communities', does this count as gentrification? These are the questions that we hope to answer in this paper. But before we begin to discuss these questions, it is important to note that until relatively recently, there has been something of a consensus that new-build developments are part and parcel of the gentrification process. Although early definitions of gentrification by authors such as Neil Smith (1982: 139) were closely aligned to Ruth Glass' (1964) classical description, it was apparent by the early 1980s that the residential rehabilitation that Glass had described was only one facet of the gentrification process (Lees et al., 2008). This led Smith (1986: 3) to argue that gentrification is:

'a highly dynamic process, it is not amenable to overly restrictive definitions; rather than risk constraining our understanding of this developing process by imposing definitional order, we should strive to consider the broad range of processes that contribute to this restructuring, and to understand the links between seemingly separate processes.' 
As a result, Smith (1996) developed his definition, arguing that gentrification had departed from Glass's description:

'In my own research I began by making a strict distinction between gentrification (which involved rehabilitation of existing stock) and redevelopment that involved wholly new construction .... and at a time when gentrification was distinguishing itself from large-scale urban renewal this made some sense. But I no longer feel that it is such a useful distinction ... Gentrification is no longer about a narrow and quixotic oddity in the housing market but has become the leading residential edge of a much larger endeavour: the class remake of the central urban landscape' (Smith, 1996: 39).

As Sharon Zukin (1991: 193) argues, when real estate developers woke up to the financial gains generated by offering a 'product based on place', gentrification quickly expanded to include a varied range of building forms. That new-build gentrification was a type of gentrification became generally agreed upon.

What is interesting, however, is that statements such as Smith's have recently become the focus of criticism among a number of authors who argue that inner city new-build developments are not a form of gentrification. Instead, they prefer terms like 'reurbanisation' or 'residentialisation' (e.g. Lambert and Boddy, 2002; Butler, 2007b; Boddy 2007; Buzar et al., 2007). These debates are largely hinged upon a particular understanding of postindustrial urban demographic change that conceptualises neighbourhood population change to be a form of replacement, not displacement (e.g. Hamnett, 2003a,b). This paper problematises this demographic narrative. However, before doing so, it is important to outline both the histories and trajectories of new-build gentrification, and consider the relationship new-build gentrification has with displacement. This discussion is, in turn, used to inform three case studies of new-build gentrification in London. We conclude by asserting the importance of moving towards a critical geography of new-build gentrification.

\section{THE HISTORIES AND TRAJECTORIES OF NEW-BUILD GENTRIFICATION}

Despite the renewed interest, until recently, there has been little in-depth research into new-build gentrification. One of the few detailed early studies was Caroline Mills' (1988, 1989, 1993) research on Fairview Slopes, in Vancouver, Canada (Fig. 1). There developers, architects, and marketing agents created a newly built landscape of gentrification, new townhouses, and condominiums, one that demonstrated processes of capital reinvestment, social upgrading, and middle-class colonisation. Mills argued:

'By focusing on the renovated housing stock there has been a relative neglect of other potentially relevant property changes.' (Mills, 1988: 6)

Importantly, Mills (1988: 186) questioned whether the redevelopment of Fairview Slopes was in fact gentrification at all:

'Yet Fairview Slopes does not fit the usual image of a gentrified neighbourhood. It is a landscape of redevelopment, and renting is probably still as common as owner occupancy.'

Nevertheless, she answered the question assertively by saying yes, indeed it is gentrification but it is a gentrification aesthetic that has moved on from classical gentrification - as she argued:

'... Just as blue jeans became the international uniform of the new class...so gentrified housing became its international neighbourhood ... Ironically, as blue jeans turned into a new conformity, so does the landscape distinctiveness of the gentrified neighbourhood.' (Mills, 1988: 186).

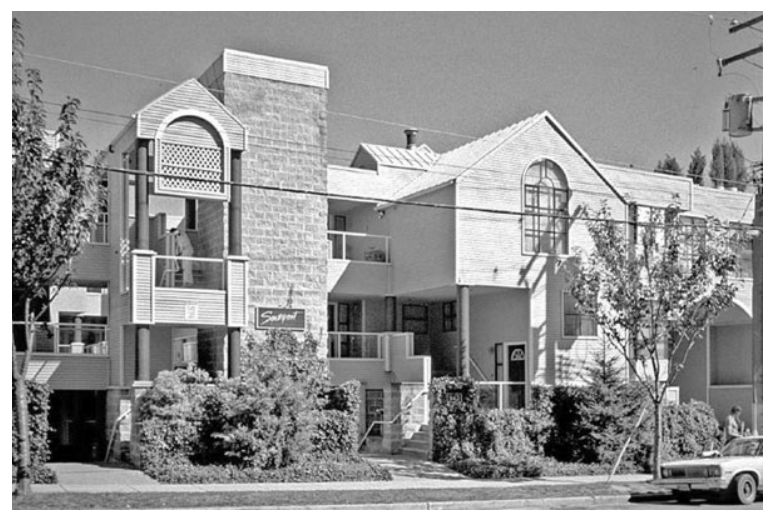

Figure 1. New-build gentrification in Fairview Slopes.

Popul. Space Place 16, 395-411 (2010) DOI: $10.1002 / p s p$ 
This new conformity is evident around the world today in the form of a gentrification blueprint that has become the leading edge of neoliberal urbanism (Lees et al., 2008). Gentrification is now a global urban strategy (Smith, 2002) used in cities that must be sophisticated entrepreneurs (Harvey, 1989, 2000; Hackworth, 2007). Development in Vancouver's Downtown South neighbourhood during the mid- to late 1990s provides a stark illustration of this. Whereas in Fairview Slopes, a decade earlier, gentrification had been the result of a number of different actors, including gentrifiers, architects/developers, marketing agents, and the local state; by the 1990s, the local state was the lead actor. In 1991, the City of Vancouver drew up the Downtown South Community Plan to construct a high-density, mixed-class residential neighbourhood to replace the gritty southern section of Granville Street, which was home to drug dealers, prostitutes, the homeless, and $14 \%$ of the city's overall low-income housing, mostly in the form of single room occupancies (SROs) (Lees and Demeritt, 1998). The plan stated:

'There will be a progressive dilution of illegal activities as more newcomers move into the area and the neighbourhood changes. Granville Street will gradually change as more people live and work in the surrounding area. Their purchasing power will slowly transform the type and availability of commerce on the street.' (City of Vancouver, 1991: 55)

The number of housing units on the site increased from 2700 in 1991 to approx 12,000 units today, of which only 1000 are non-market. The idea has been to attract those interested in high-density urban living. When the redevelopment began, $70 \%$ of Downtown South's low-income and SRO housing was privately owned, making residents especially vulnerable to direct displacement. The City sidestepped the accusation of gentrification by charging developers about to demolish SRO housing \$1000 per unit to go into a fund earmarked for future social housing. Today, Downtown South is a glittering new-build middle-class residential neighbourhood (Fig. 2), and the preexisting low income community is largely absent, having suffered massive displacement.

Vancouver's Downtown South can be seen as an early example of third-wave gentrification: state intervention (Shaw, 2005) and the large-

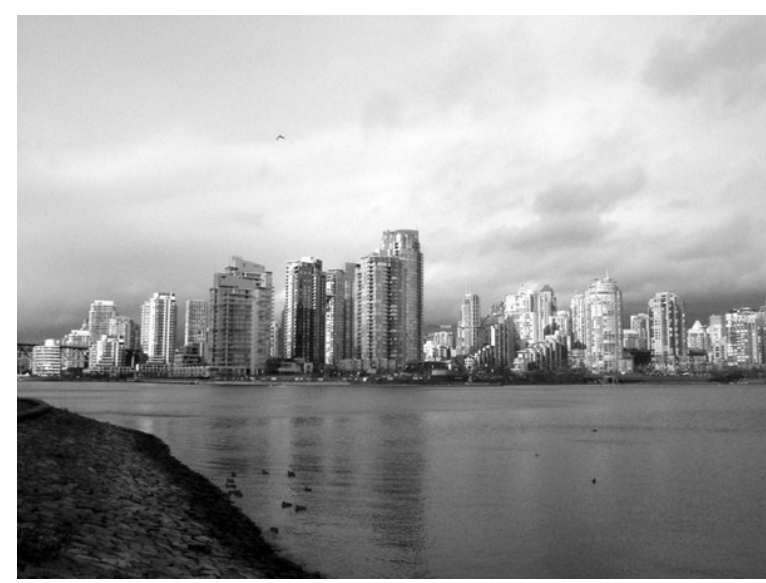

Figure 2. Downtown South, Vancouver.

scale deployment of capital (Hackworth and Smith, 2001). In recent years, however, new-build gentrification has become even more closely intertwined with government interventionism, sold through policy discourses about 'mixed communities'. Socially mixed neighbourhoods have become a major urban policy and planning goal around the globe (see Lees and Ley, 2008). Cameron (2003: 2373) calls this 'positive gentrification' or 'gentrification as a positive public policy tool'. One of the most notable programmes has been the US Federal Department of Housing and Urban Development's (HUD) HOPE VI (Home Ownership and Opportunities for People Everywhere) Program. This showpiece of Clintonera urban policy has been used over the past decade to socially mix - read gentrify - public housing in order to break down the perceived culture of poverty and the social isolation of the poor (see Lees, 2008; Lees et al., 2008). The fall out has been significant displacement and homelessness (see Smith, 2001; Shaw, 2007).

HOPE VI and its related programmes of social mixing constitute what Wacquant (2008: 199) calls the 'literal and figurative effacing of the proletariat in the city ...'. This effacement is about population displacement on both a micro (neighbourhood) and a macro (central city) scale. It is at its most visceral in the state-led new-build gentrification of post-Katrina New Orleans, where the agencies in charge of public housing (including HUD) are using storm damage as a pretext for expelling working-class African-Americans in a very blatant attempt to co-opt homes and sell them to developers to build high-priced housing 
(see Lees et al., 2008: 185-187). But this effacement is also happening in cities like London, too, as we demonstrate.

\section{CHALLENGES TO, AND DEBATES OVER, NEW-BUILD GENTRIFICATION}

In 2002, Lambert and Boddy spurred a new debate about new-build gentrification. They questioned whether new-build city centre residential landscapes can be characterised as gentrification. They saw some parallels in terms of new geographies of neighbourhood change, new middle class fractions colonising new central urban spaces, and attachment to a distinctive lifestyle and urban aesthetic:

'... But (for them) "gentrification", as originally coined, referred primarily to a rather different type of "new middle class", buying up older, often "historic" individual housing units and renovating and restoring them for their own use - and in the process driving up property values and driving out former, typically lower income working class residents.' (Lambert and Boddy, 2002: 20)

They concluded that to describe these processes as gentrification was stretching the term too far. Debating this position, we drew up the cases for and against new-build gentrification, and we found more evidence for 'the case for' (Davidson and Lees, 2005). Referring to cases of new-build gentrification along London's Thames, we argued that although direct displacement could not occur because these were brownfield sites, indirect displacement was likely to occur instead. This indirect displacement, we argued, would take the form of 'exclusionary displacement' or price shadowing, where lower income groups would be unable to access property. We also stated that it might cause socio-cultural displacement as the incomers took control of community apparatus. Importantly, we pointed out that unlike the direct displacement tied to traditional processes of gentrification, indirect displacement can avoid legislation (planning or other, e.g. antiwinkling laws) that seek to protect poorer inner city residents from displacement.

In a recent review of Davidson and Lees (2005), Boddy (2007) was not persuaded by our evidence about indirect displacement. Davidson (2008, 2009a), however, has elaborated on our earlier findings, providing detailed empirical evidence to further substantiate our claims. He has produced qualitative evidence of population change and of the various forms of indirect displacement: economic, political, and service/commercial. Displacement - the disinvesting and loss of place - takes place via many processes. Some time ago now, Marcuse (1985) conceptualised four types of displacement:

(1) Direct last-resident displacement: this can be physical (e.g. winkling - when landlords cut off heat in a building, flood it, or set fires in it, forcing the occupants out) or economic (e.g. rent-hike eviction).

(2) Direct chain displacement: this goes beyond standard 'last resident' counting and includes previous households who were forced to move out due to deterioration of the building or rent hikes.

(3) Exclusionary displacement: here residents cannot access housing because it has been gentrified (or abandoned).

(4) Displacement pressure: this is the dispossession suffered by low income groups during the gentrification of their neighbourhoods.

Davidson (2008, 2009a,b) ${ }^{2}$ focusing specifically on new-build gentrification, draws on and adds to Marcuse's schema; the displacement happening is not the simple 'eviction and rent hike' displacement that is common to the literature and part of Boddy's arguments; it is much more nuanced than that.

Boddy (2007) simplifies and under-theorises displacement. His research was based on a 'qualitative survey of senior representatives of development companies, architectural practices, and property agents based in Bristol together with public sector agencies including local authority planning staff' (Boddy, 2007: 87); in other words, with 'elites' with a vested interest in refuting the label 'gentrification'. Boddy (2007) prefers the class neutral label 'reurbanisation'. Indeed, the concept of reurbanisation has come to be used to argue against 'new-build gentrification'. Reurbanisation is defined as the stabilisation of innercity residential districts by increasing in-migration (of new or non-traditional household types with explicitly city-minded housing preferences) and decreasing outmigration after a long period of 
negative migration balance (Haase et al., 2007). As Buzar et al. (2007a: 64-65) explain, 'reurbanisation' was first used in the late 1970s and early 1980 s as a theoretical concept to refer to the opposite of deurbanisation and deconcentration. It was a process driven by the 'second demographic transition' ${ }^{3}$ Reurbanisation, which leads to residentialisation, it is argued, can therefore improve quality of life and use of inner city space (see Haase et al., 2005, 2007).

The crux of the difference then is that reurbanisation, unlike gentrification, does not result in displacement. Yet those who favour the label 'reurbanisation', and, in turn, make arguments about population 'replacement' opposed to 'displacement', forget the scale biases in their theses. As stated, 'reurbanisation' emerged in the context of broad discussions about the population trends of central cities, metropolitan regions, and rural areas. If used to discuss the specifics of inner city changes (e.g. Boddy, 2007), then the implication is that those who are forced to leave a metropolitan region due to housing prices are victims of gentrification-induced displacement at the scale of the entire metropolitan region. The corollary for Hamnett's $(2003 a, b)$ replacement thesis would be that all of London has become a giant displacement machine for anyone unable to compete in its intensely commodified and overheated housing market. The problems of gentrification and affordability are interrelated as lower income households (and even some middle income households) are outbid by high income/ affluent households. ${ }^{4}$

Butler (2007b) makes a slightly different set of arguments as to why areas in London's Docklands are being reurbanised, not gentrified. He argues that the developments that he has looked at display some of the characteristics of suburbia - they are gated (cr. Atkinson, 2006), and the residents (gentrifiers) are more fearful of the socially mixed environments of inner London, making them qualitatively different to those he interviewed elsewhere in inner London. He argues that their aspirations echo, not those of the gentrifier, but those of the classic 'suburbanizer' - 'to be near but not in or of the city' (Butler, 2007b: 777). Yet how is this different to what Mills (1988) found in the gated Maximilian project in Fairview Slopes, or what Lees (2003a: 2490) found in the super-gentrified Brooklyn Heights, New York City? The process of gentrification is rarely enacted these days by a pro-social mixing gentrifier, the pioneer gentrifier of old, and indeed hasn't been for some time (Lees, 2008).

\section{POPULATION REPLACEMENT OR DISPLACEMENT?}

\section{Hall and Ogden (2003: 874) argue:}

'In order to understand the demographic and, in particular, household changes that have been taking place in London, it is essential to understand London's role as a global city and the labour market changes consequent upon this.'

Hamnett's (1994, 2003a,b) professionalisation thesis - which argues that London is professionalising (not gentrifying) via population replacement (not displacement) - is a particular reading of this. Commenting on Atkinson's (2000) analysis of the relationship between gentrification and displacement in London, Hamnett (2003b) argues that the association between population growth in one group (middle-class professionals) and decline in another (the working classes) cannot be read as evidence of displacement:

$' \ldots$ it is argued here that the slow reduction of the working class population in many innercity areas is, in part, a result of a long-term reduction in the size of the working-class population of London as a whole (by a combination of retirement, death, out-migration or upward social mobility) and its replacement by a larger middle-class population. In other words, the key process may be one of replacement rather than displacement per se.' (Hamnett, 2003b: 2419)

Hamnett is able to make this assertion because the aggregated data of the UK census cannot prove displacement; however, neither can it demonstrate the absence of displacement! There is no statistical data available that quantifies displacement in a convincing way (Slater, 2009). And the data sets available are ill-suited for an 'analysis of the full social complexity of individual and family circumstances' (Newman and Wyly, 2006: 42).

Watt (2008) argues that Hamnett (2003a,b) exaggerates the expansion of the middle classes in London. He points out that Hamnett's choice of data ${ }^{5}$ omits the presence of a large group - the 
economically inactive (the long-term unemployed, the sick, disabled, and the elderly, many of whom are likely to be working class). In addition, Watt $(2006,2008)$ points out that Butler, with Robson's argument that London's working classes have declined and lost social significance, is undermined by the fact that they themselves state 'middle-class households tend to comprise about a quarter of the population' (2003: 6). Watt (2008) asks: 'If this is the case, then what can we deduce about the remaining three-quarters?'

Following Hamnett (1994; 2003a,b), Butler et al. (2008: 72) argue that labour market changes have resulted in a more professional socio-economic structure: 'the numbers in intermediate social groups have not been squeezed out, as the social polarisation thesis would suggest, but have grown'. Tables 1 and 2 shows that by 2001, London was well represented by highly qualified and highly skilled people, and while temporal comparisons are difficult to make with regards to occupational classifications (Oesch, 2006), there is little doubt this represents a significant transition from London's occupational profile in the 1960s and 1970s (Congdon, 1989; Hall and Odgen, 2003). However, this overlooks London's finescale population and social geography.

In a fine (ward) scale analysis of population and social change in London in the 1980s, Congdon (1989) found that both macro and micro geographies of social inequality have been persistent in the city. He wrote: '[S]mall area monitoring of social indicators is important in the view of evidence that deprivation may be spatially concentrated, with pockets of deprivation in otherwise prosperous areas' (Congdon, 1989: 489). Such studies are pertinent in the face of recent characterisations of London as a middle class city that have understated the continued presence of working-class populations across the city. Figure 3 illustrates the continued and important presence of working class populations (see Slater, 2006, 2009; Smith, 2008; Wacquant, 2008 on the effacement of the working classes in the gentrification literature).

Furthermore, Butler et al.'s (2008) statistical evidence for the expansion of the middle classes in London is problematic. Two-thirds of the total middle-class growth they found during 19912001 occurs in the socio-economic groups (SEG) ${ }^{6}$ 5.1 (ancillary workers and artists) and 5.2 (foremen and supervisors non-manual). They claim this represents a substantial growth in the intermediate middle classes, but a close examination of the SEG 5.1 and 5.2 occupations demonstrates that, in fact, many in these groups cannot be considered middle class at all, for they include: counter clerks and cashiers, debt, rent and other cash collectors, dental nurses, sales assistants, and petrol pump forecourt attendants, among others (see Rose and O'Reilly, 1998). This shows the difficulty in measuring post-industrial class divisions (Oesch, 2006); moreover, the occupations grouped in these SEGs clearly demonstrate working-class presence, as well as middle-class growth (see Watt, 2006, 2008).

Another problem is that displacement is regularly conceived of as a singular outcome, not as a complex set of (place-based) processes that are spatially and temporally variable. This can be seen clearly in other gentrification work too. Freeman $(2005,2006)$, for example, used a series of interviews with African-American residents in Harlem and Clinton Hill, New York City, to question the extent to which people are displaced through gentrification, arguing it is perhaps a more gradual process that, although displacing some, leaves its imprint mainly by changing who moves into a neighborhood' (Freeman, 2005: 488). In both quantitative research that has sought to measure the extent of spatial dislocation (Atkinson, 2000; McKinnish et al., 2008) and qualitative work that has defined the significant absence of displacement via the presence of incumbent communities (or parts of) at the time of research (e.g. Freeman, 2005), displacement is too often reduced to the brief moment in time where a particular resident is forced/coerced out of their home/neighbourhood. The denial of displacement here, just as in critiques within the new-build gentrification literature, is premised upon a particular spatial and temporal understanding of displacement that does not adequately conceptualise the process. This explains why authors who search for the spatial moment of displacement often contradict themselves, for example, Hamnett and Whitelegg (2007: 122) on gentrification and displacement in Clerkenwell, London:

'Their arrival [gentrifiers] and the associated commercial gentrification have, however, significantly and probably irrevocably changed the social mix and ethos of the area which was 


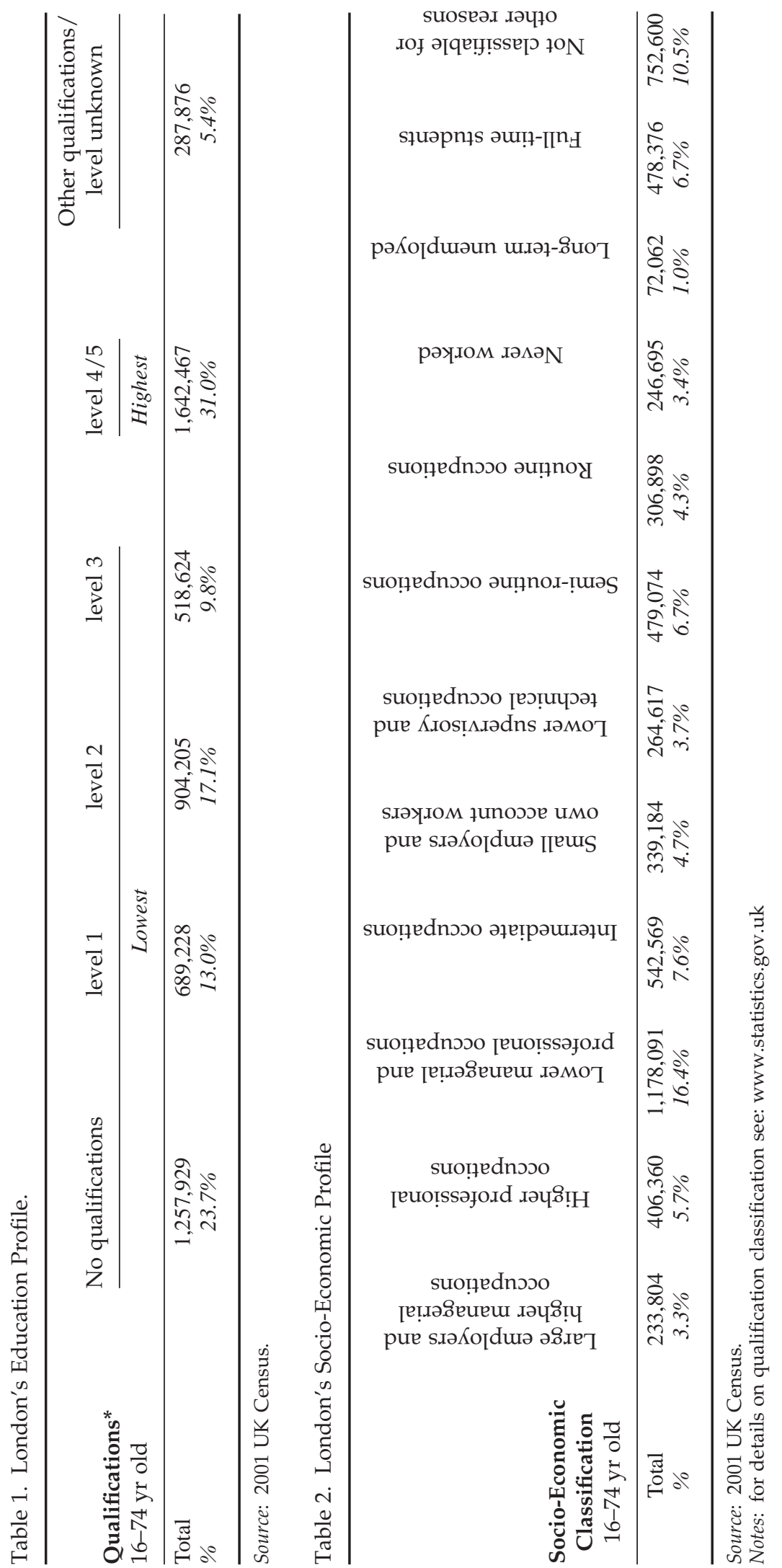




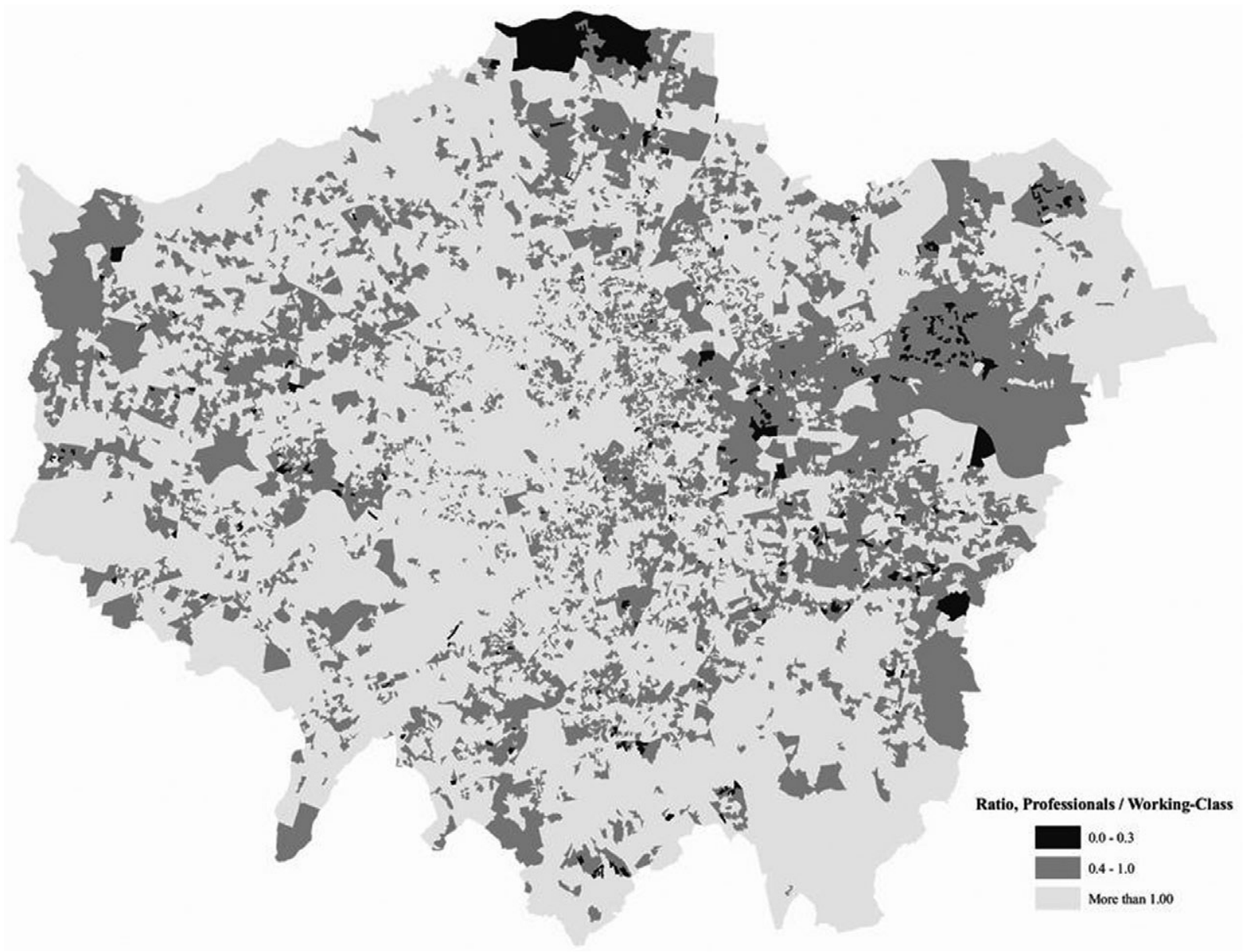

Figure 3. Geography of working class neighbourhoods.

Notes: Ratio is based upon 'middle-class' socio-economic classifications (SECs) (large employers; higher professionals; lower professionals) and 'working-class' SECs (lower supervisory, semi-routine, and routine).

dominated by social rented housing tenants. This has not, however, been accompanied by significant residential displacement.'

As Slater (2009) argues they have missed Marcuse - for what they are describing is Marcuse's (1985, 1986) 'displacement pressure'.

\section{QUALIFYING DISPLACEMENT: THE PHENOMENOLOGY OF PLACE}

Yi Fu Tuan (1977) distinguished space from place by emphasising that the latter represents security and the familiar. With reference to the home, Tuan (1977: 144) stated: '[h]ome is an intimate place. We think of the house as home and place, but enchanted images of the past are evoked not so much by the entire building, which can only be seen, as by its components and furnishings, which can be touched and smelled as well'. Tuan extends this to the hometown: '[h]ometown is an intimate place. It may be plain, lacking in architectural distinction and historical glamour, yet we resent an outsider's criticism of it. Its ugliness does not matter; it did not matter when we were children, climbed its trees ...' (Tuan, 1977: 144145). ${ }^{7}$ Fellow humanist geographer Relph (1977) echoed this by arguing that place plays a key ontological role: anchoring identity and existence. The point here then is that displacement is much more than the moment of spatial dislocation. To reduce displacement to that moment is to strip meaning from lived space (Davidson, $2009 b$ ). To dismiss the phenomenological basis of 
place simply reduces neighbourhood to a spatial commodity, and, of course, this is the understanding that underlies neoliberal urban policies (cr. Allen, 2008).

A phenomenological reading of displacement is a powerful critique of the positivistic tendencies in theses on replacement; it means analysing not the spatial fact or moment of displacement, rather the 'structures of feeling' and 'loss of sense of place' associated with displacement. This requires a move to reassert the place in displacement. As Slater (2009) points out, many qualitative studies of gentrification (see Fried, 1963; Hartman et al., 1982; Hartman, 2002; Betancur, 2002; Curran, 2007) have uncovered a sense of bereavement in association with being displaced, especially for older people. It is these 'emotional geographies' that provide the best evidence of displacement. For as Tuan (1977: 3) claimed: 'place is security, space is freedom: we are attached to one and long for the other'. Hartman's (1984) 'right to stay put' requires extension to 'the right to (make) place; the right to dwell' (Davidson, 2009b).

\section{NEW-BUILD GENTRIFICATION IN LONDON}

As established areas of gentrification in inner London have matured, it has been new-build gentrification (state-led and funded/co-funded by corporate capital) that has pushed the process further into, and across, a diverse range of the city's low-income neighbourhoods. The exclusive and often gated built form of new-build gentrification has been central to this encroachment. Whereas the collective action of classical gentrification focused on areas where existing housing stock enabled a new middle-class habitus to be created (e.g. Bridge, 2001; Butler, 2003), newbuild developments are pushing gentrification into the remaining working class neighbourhoods and ultra-marginal areas (Davidson, 2007). Some of these areas are large-scale council estates; the Aylesbury Estate south of Elephant and Castle in Southwark is one such example. The largest public housing estate in Europe it is in the process of being demolished and replaced with a new 'mixed income community' (Fig. 4).

In 2005, Southwark Council decided that the estate was too expensive to refurbish and that demolition was the most cost effective solution. They set about persuading tenants that the estate was structurally unsound and not a pleasant

Copyright (c) 2009 John Wiley \& Sons, Ltd.

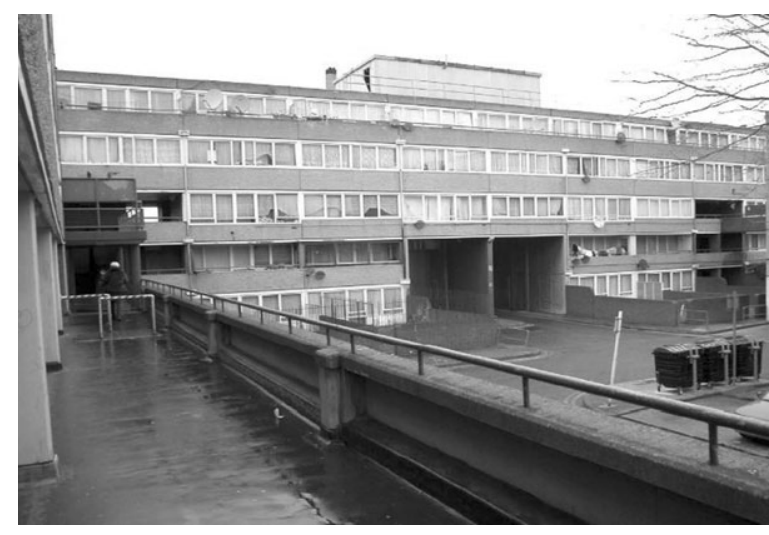

Figure 4. The Aylesbury Estate.

place to live. Here, new-build gentrification is not taking place on an ex-industrial brownfield site; rather, like in Fairview Slopes, it is taking place on pre-existing residential land. Given the pressure under the government's 2000 Decent Homes Standard requiring better council house standards, but giving local authorities no funding to achieve this, it is not surprising that Southwark Council has gone down this road. The current strategy for the demolition and rebuilding of the Aylesbury estate (The Aylesbury Estate: Revised Strategy, 2007) lists the construction of 3200 private new-build homes and 2000 social rented new-build homes. This fulfils the UDP requirement for $40 \%$ social housing. In essence, they seek to demolish the vast majority of the Aylesbury (despite much of it being structurally sound) and to create a $£ 2.4$ billion new-build development for a privileged middle class.

In this particular case, it is critical to see the relationship between the notion of creating mixed communities and displacement (see Lees, 2008). The regeneration of the estate as suggested in current plans will directly displace approximately $20 \%$ of the existing tenants, the existing leaseholders who bought under 'right to buy' will also be priced out/displaced, and the remaining 1850-2050 council tenants might move into new homes, but they will be indirectly displaced into a new middle-class community very different that which they leave behind.

In 2002, a similarly strapped-for-cash Lewisham Council sold off Aragon Tower, a council tower block on the Pepys Estate in Deptford, adjacent to the Square Mile, to the private 
developer Berkeley Homes for over $£ 10$ million (Fig. 4). ${ }^{8}$ Berkeley Homes has renovated the highrise and added five extra floors of newly built flats on the top, making it the tallest privately owned residential tower block in London (Fig. $5)^{9}$. Their market is young professionals, whom Lewisham Council hopes will regenerate the area. This gentrified tower block is not a classically gentrified historic property, a Georgian or Victorian house, it is a modernist building that has not been renovated to highlight its prior architectural and aesthetic state. In fact, it has been re-clad to erase its old aesthetic. But neither is it strictly new-build gentrification, although it does incorporate an element of this in the five newly built floors, including 14 penthouse units that have been added to the top of the high rise. It is a gentrification hybrid.

The low-income council tenants were moved out, and middle-income owner-occupiers moved in; the tower block (renamed the $\mathrm{Z}$ apartments) was gated, and a security guard installed to protect the residents and their cars. One resident, a leaseholder who had lived in the high-rise for

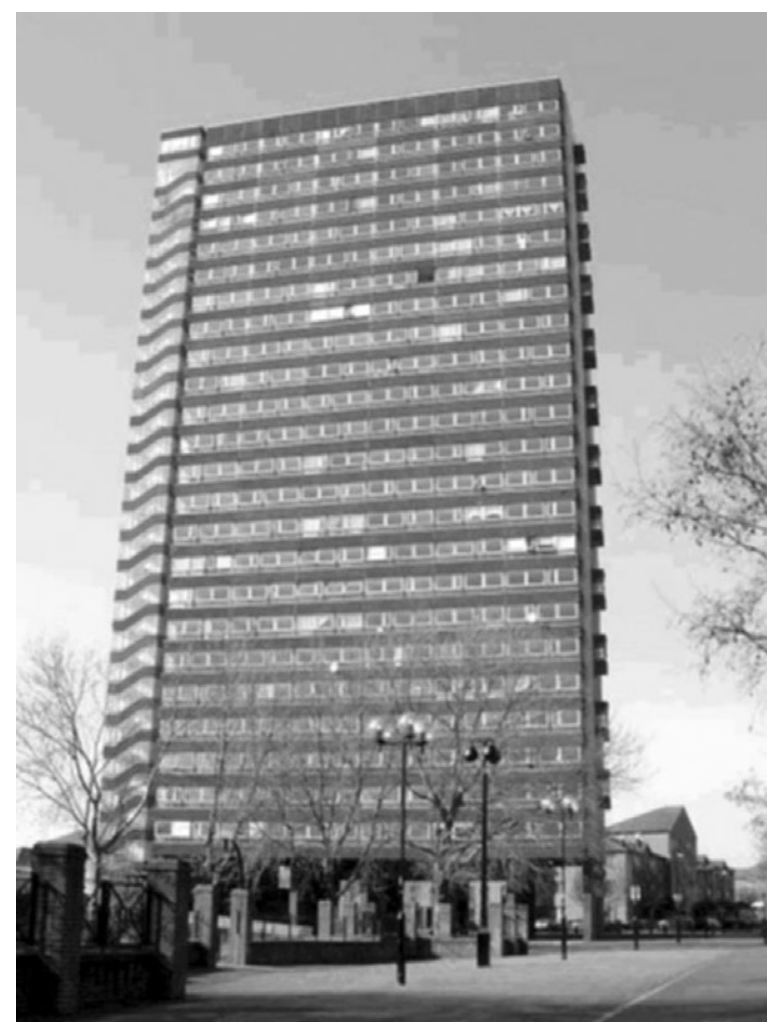

Figure 5. Aragon Tower.
20 years, and did not want to move out, was offered a less than market value buy back from the Council, which he rejected. The Council threatened him with an eviction order (classic gentrification-induced displacement), but he finally sold out at market value after hiring a solicitor to argue his case (Lonsdale, 2004)!

\section{EVIDENCE OF DISPLACEMENT ALONG LONDON'S GENTRIFYING RIVERSIDE}

Along the length of the metropolitan Thames, derelict and industrial sites have been transformed into some of the most desirable residential space in London. These developments, numbering in the hundreds, include the opulent Richard Rogers-designed Montrevetro, Battersea, and the Foster and Partners-designed Albion Riverside, Battersea, as well as the Z Apartments discussed above. In the three neighbourhoods discussed here - Brentford, Wandsworth, and Thamesmead (Fig. 6) - approximately 2100 housing units have been added through newbuild gentrification, increasing the populations

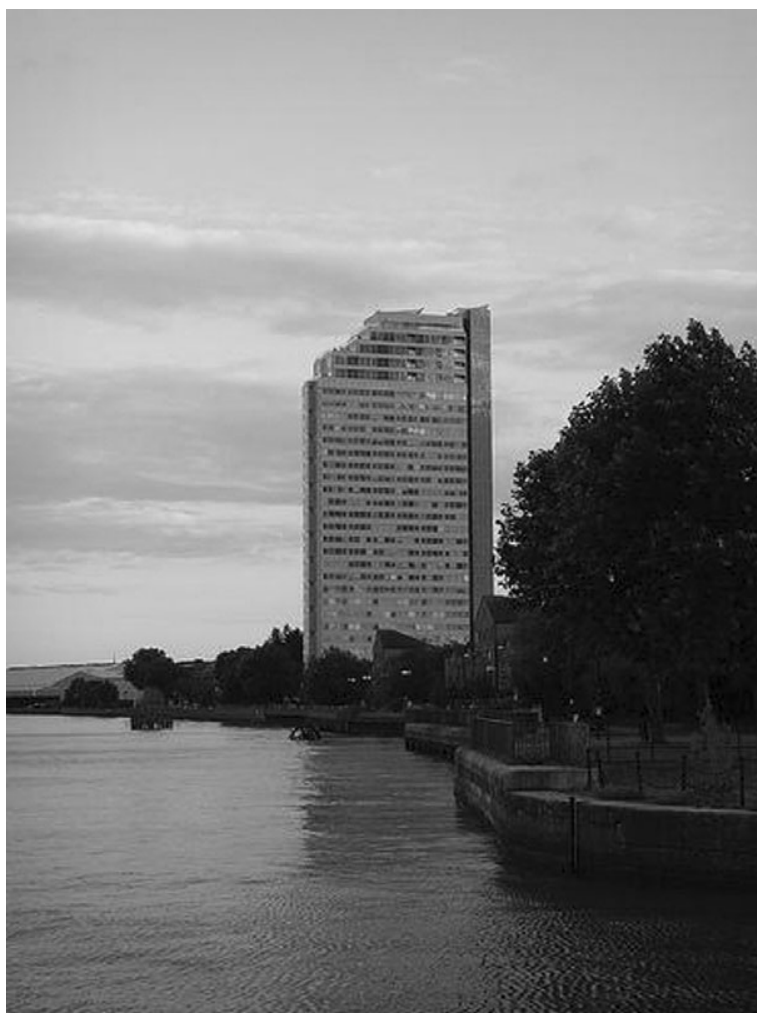

Figure 6. The new Z Apartments. 
of the wards by, on average, $60 \%$, with the majority (over $80 \%$ ) of the new population being highincome earners (socio-economic classification's 1-4). Many of these new residential developments have been built upon ex-industrial sites, such as power stations, docks, and rail yards, which used to provide employment to the surrounding working class communities. All this new-build development is comprised of highdensity apartment buildings, built by large corporate developers (Fig. 7). Reflecting New Labour's Urban Renaissance policy vision (see Lees, 2003b, 2008), each of these neighbourhoods has therefore experienced social upgrading (sold as social mixing), new high-density development, and brownfield reuse. The result is displacement - this has already occurred - and if the process of gentrification continues in these areas, further displacement will emerge.

However, the population turnover and social upgrading that has occurred along the length of the Thames does not reveal the full extent of working class displacement. Unlike the blatant state-led displacement at the Aylesbury Estate, much of the displacement along the Thames has played out in more silent registers. In order to comprehend this complex set of processes, we must move beyond population data and highly symbolic rent hikes and forced evictions. Indeed, this is a necessary step if we are to understand displacement's social significance (see Davidson, 2009b).

We outline the various modes of displacement operating along the Thames by drawing upon 41

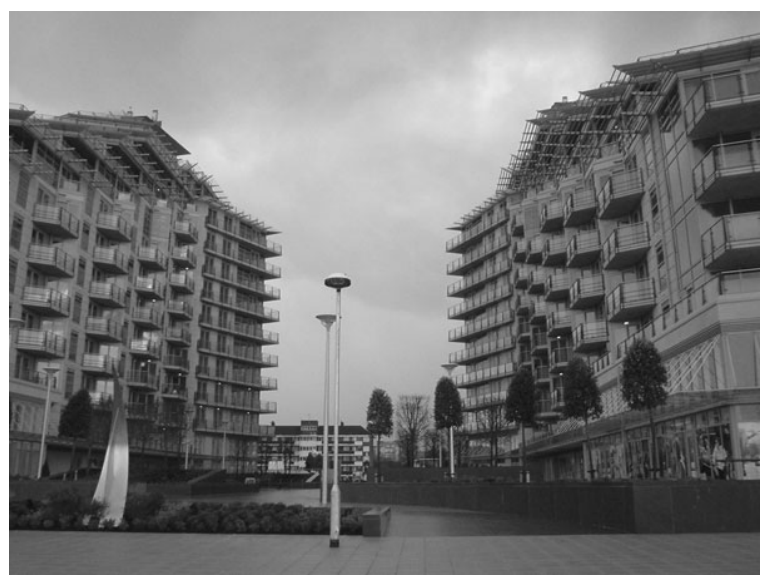

Figure 7. High-density development along the Thames. in-depth interviews undertaken with working class residents in 2004-2005. In each neighbourhood, we identify various arrangements/collections of context-bound indirect displacement processes. As a whole, they demonstrate the various ways in which phenomenological understandings of 'home' and 'neighbourhood' have been dismantled through gentrification. While interviewed residents often remained in the neighbourhoods, a set of displacement processes have occurred that mirror the impacts of physical displacement: the forced disconnection from familiar place and the (phenomenological) relocation into a new urban social context.

\section{Brentford}

Over the past decade, Brentford has been subject to wholesale gentrification, predominantly via new-build development. During the early stages of new-build gentrification in 2002, national newspapers were describing Brentford's gentrification in dramatic fashion: 'The best houses in [ Brentford] ... would probably reach $£ 1$ million now ... they have been held back by the lack of local facilities. Brentford does not yet provide the seared tuna and decent cappuccino array taken for granted by the rest of middle-class London... The new developments will change all that, and prices are expected to soar as a result' (Purnell, 2002). As new-build gentrification has delivered 'decent cappuccinos' (via the displacement of incumbent retail services), working-class residents have described neighbourhood change in less than glowing terms: 'New buildings are good, we need them. But I'm just uneasy about it, for some reason. Erm . . . , I don't know, something just bites me. If I was to try and put a finger on it, I guess it would be that I feel disconnected from it ... I mean, I'm not sure what it has to do with us [interviewee's family]'.

Many working class residents struggled to identify how recent reinvestment improved their neighbourhood. When questioned on the benefits of the reinvestment, a local resident of 30 years commented: 'The biggest thing I've seen in terms of benefit is the young girls getting jobs working at the hotel [incorporated within a 'mixed-use' new-development]. You know, as maids. So it has given work... But saying that, they will never be able to live here. When they get a bit 
older, get married and that, unless the council starts putting up new houses, they will have to leave. I think that is a pattern'. When asked to clarify if this constituted an improvement for the incumbent community, the interviewee responded: 'Well a job is a job, but I guess if you compare things to when we first got here, it fits with my general view that it keeps being rundown ... It is nice for the girls to have work, but you could ask if it fulfil promises. You certainly don't have the vibrant working community where we all knew each other now'. Here, a perception of built environment improvements stands alongside a generally held narrative of decline and disassociation. New-build gentrification was commonly viewed as an agent of neighbourhood change, but one that held few positive associations for many working class residents. Interviews often focused upon the impending prospect of increasingly unaffordable housing and, consequently, exclusionary displacement (Marcuse, 1986).

As gentrification transforms Brentford, in terms of reorienting local retail services and reconstituting the built environment, working class residents have seen neighbourhood places (i.e. sites of collective and personal association) lost and claimed by a new population. For example, one long-term resident described the newly redeveloped riverside as 'not our space now', and another talked of it as 'a bunch of canyons where I [interviewee] would not feel comfortable'. The implications of this sense of loss were varied. For a 60 -year old female interviewee, it meant that she was 'thinking of moving away now there was little to stay for'. A growing sense of neighbourhood disattachment also coalesced with the problem of the increasingly unaffordable housing market. For example, the organiser of a local church group that attempts to foster local community through art events commented: 'Ithas becomeharderfor us ... Young people have either moved on or can't live here. Put that with a sense that getting the neighbourhood together is an uphill battle and you have our situation ... It is sad to say, but I'm not sure the future is all that happy'.

While these interviewees still remained within Brentford (i.e. were not physically displaced), they had experienced significant displacement. Their 'neighbourhood' had changed, usually without their input. Change had not served their needs; indeed it has reduced a number of local provisions. For some, relocation was pending or even now preferable to living in a place they no longer had personal or collective investment in.

\section{Wandsworth}

In Wandsworth, gentrification has been ongoing for 20 years longer than in Brentford. As a consequence, interviewed residents articulated a more advanced sense of displacement, one laden with feelings of bereavement, dislocation and disassociation: 'You ask me about how the place has changed, well I'm not sure I can say. All I know is that what used to be here is not now. Most of the community has gone, and I don't know that many of the youngsters have managed to stick around ... All the new flats represent the end really'. For this interviewee, new-build gentrification represented the conclusion of wider gentrification processes: 'If we are talking about where I would associate with, I'd honestly say it would be Wimbledon now. That's where I go shopping now. Gone are the days when I might meet friends here [Wandsworth] ... You know, this place is unrecognisable, just a few remnants like us around'. A once strong socio-spatial bond, integral to the subject's being (Davidson, 2009b), had therefore been dissolved through a classbased process of neighbourhood change.

Given the advanced stage of gentrification, much of the retail landscape has been transformed in Wandsworth. High-end boutiques, restaurants, and food stores have progressively replaced previous facilities. Many residents saw 'improvements' for others and not for them: 'You definitely have snazzy shops in Wandsworth now, a bit like Fulham. Not that they are really me, you know ... I would find some of the pubs [and stuff] a bit intimating, just not what I would be comfortable around'. Losing retail services meant sites of association had progressively diminished for many residents. Some simply conveyed a sense of disappointment; others were more concerned that local government had intentionally pursued exclusionary policies: 'If you look at how things have changed, bringing in all the rich folk, you can see the council obviously wanted it ... They are only interested in getting more money... When it comes to people like me, they don't care. They probably think we are happy with the crappy bits left over'. 
For many working-class residents, new-build gentrification therefore meant the end of a long period of displacement. 'Neighbourhood' no longer signified the same sense of attachment; no matter how romantic or problematic this might have been. Instead, local place had often been reduced to home; collective existence now took place within four walls and extended little further. And for some, the loss of communal neighbourhood associations had shifted perceptions of home:'IfI'mhonest,Iused tolovemy house . . . particularly when the door was always open and all that ... But it can feel a bit empty now ... erm ... how can I put it ... like you just don't have the same connection, like you would not stand on the step and see the same neighbours'.

Wandsworth interviewees demonstrated the connections between spatial and place-based displacement. The significant physical displacement that had taken place over the past 30 years had not left those working class residents who remained fortune beneficiaries (see Freeman, 2005). Rather, many suffered significant displacement through transformations of social networks, housing markets, and services. The very community ties that a New Labour government has heavily promoted (Lees, 2003b, 2008) have been destroyed; finished off by a swath of new-build gentrification.

\section{Thamesmead}

The western edge of the 1960s-constructed Thamesmead new town has experienced significant waterfront development on the 1200 -acre Royal Arsenal site. Here, the pristine aesthetics of new-build gentrification and waterfront living are juxtaposed against a stigmatised social housing estate. As a consequence, the ability of developers to produce gated residential developments has been central to gentrification (see Atkinson, 2006: 826-827). At the Royal Artillery Quays development in Thamesmead West, a militarised built environment shields gentrifiers from their locale (Fig. 8). In contrast to the emancipatory liberal gentrifier (see Lees, 2000), residents view their development as distinct from the wider neighbourhood: 'To be honest, I would never walk through the area. I just drive in and out... I know it will change over time with the money being put in, but for now that is how it works for me'.

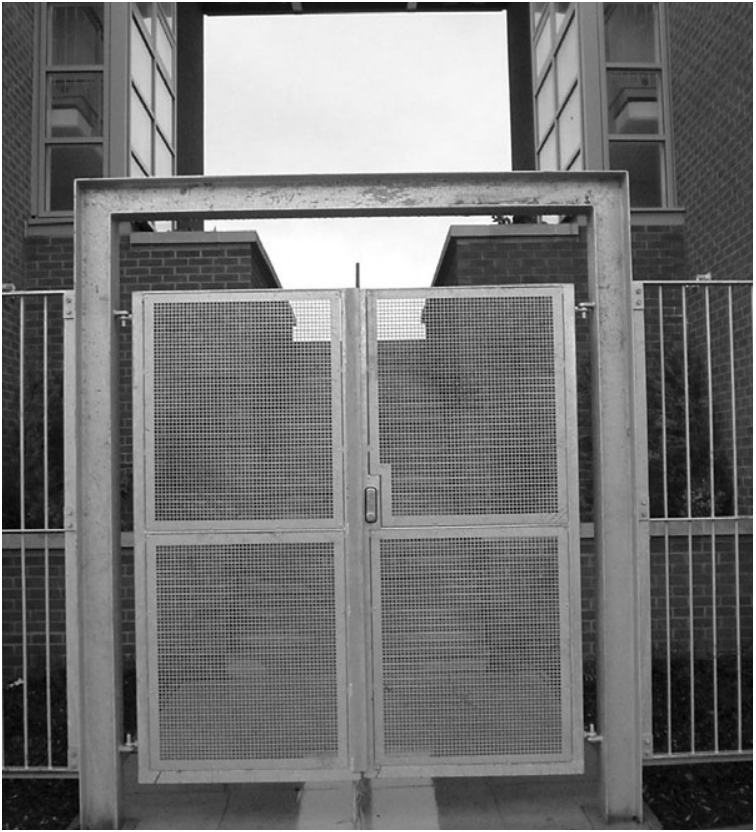

Figure 8. Gated gentrification at Thamesmead.

For the working class communities that were relocated to Thamesmead from South London's slums in the 1960s, recent gentrification has continued their lengthy experience of abandonment. As a local community worker and resident explained: 'We've tried really hard to make this place work, through all its faults. But you have always had that strange detachment thing. People were relocated here, and we've had to deal with it ... I see the new development as potentially good if it helps people, but it does have that same feeling of disconnection ... you know, how does it help? I can't see the benefits, which I think we should. There should be a wider contribution of new stuff happening'. Within the context of deprivation, this interviewee therefore saw gentrifying development as symbolic of continued abandonment.

For others, new-build gentrification was threatening their 'neighbourhood' in a multitude of ways. Some had worries that 'new apartments would drive up prices in one of the last affordable places [in London]' [i.e. direct-chain and exclusionary displacement (Marcuse, 1986)]. Others were concerned that 'places like Royal [Artillery] Quays would ensure that no local, reasonable [i.e. affordable] corner shops would ever survive' (i.e. service/commercial displacement). Particularly concerning was the impact of new-build 
gentrification upon efforts to revitalise this deprived community. Here, a twinned sense of displacement and continued abandonment meant progressive community projects were struggling to survive: 'I think we have tried so hard to make a good place here. We have tried almost everything ... So when you see the police switch from helping you to looking out for the new ones [gentrifiers] it sticks with you. You know, you try hard and your efforts don't get any support... It makes you think what is the point? I don't want to live in a place like that'. In the face of huge challenges, place-making practices in Thamesmead have therefore been diminished by the impacts of gentrification. In contrast to the displacement taking place in Brentford and Wandsworth, in Thamesmead, displacement has also taken the form of a disabler. In the face of huge social challenges, it has curbed the desire and ability to generate the necessary infrastructure of place.

\section{CONCLUSION}

We have argued that new-build gentrification has long been accepted as a type of gentrification and sketched out the contradictions in recent commentaries. We point to stunted conceptualisations of displacement, for 'displacement affects many more than those actually displaced at any given moment' (Marcuse, 1986: 157), and the misplaced conceptualisation of gentrification as reurbanisation. We also question the extent to which recent characterisations of London's demographic transition (from working class to middle class city) have captured the city's post-industrial socio-economic population profile and geography correctly.

Drawing upon multiple examples of new-build gentrification in London, we have demonstrated the diverse workings of displacement. These range from direct (spatial) displacement via stateled housing renewal projects to a host of placebased, context-bound indirect displacement processes operating in Thames-side neighbourhoods. Focusing on the latter examples, we argue displacement is both spatial and place based. In particular, we argue that a purely spatial account of displacement is inadequate. As such, we understand displacement as operating uniquely across neighbourhoods, according to the particular contexts and positionalities. However, in all our examined cases, space- and place-based displacement has been manifest for working class interviewees through a declining sense of placebased identity, anchored in and through neighbourhood spaces (Relph, 1977).

This evidence leads us to repudiate Butler's recent call for gentrification research '...to decouple itself...from its associations with working-class displacement' (2007a: 162), because as the case studies outlined here reveal, newbuild gentrification in London is causing significant displacement. These displacements are multiple: they include both direct and/or indirect displacement, they are sometimes immediate, sometimes not, sometimes they impact physical space, sometimes not. But what they all share in common is the alteration of the classbased nature of the wider neighbourhoods of inner London, of place.

In conclusion, we follow Clark in arguing for a much broader definition of gentrification, one that has a more inclusive perspective on the history and geography of gentrification and one that sees the root causes of gentrification to be 'commodification of space, polarised power relations, and a dominance of vision oversight characteristic of "the vagrant sovereign"' ((2005: 261). Like Clark, we argue that the term needs to be elastic enough to allow new processes of gentrification (like the 'hybrid gentrification' of Aragon Tower) to be drawn under its umbrella. And as we have argued before (see Davidson and Lees, 2005; Lees et al., 2008), the term 'gentrification' captures the politics that are inevitably present when neighbourhood change is premised upon social class, and, at the same time, it invokes a politics that does not accompany terms such as 'reurbanisation', 'residentialisaiton', 'transition', or 'replacement'.

\section{POSTSCRIPT}

The onset of the current recession has impacted the new-build developments in the more marginal areas along the Thames, e.g. Thamesmead, with developers being unable to sell apartments, prices falling, and high vacancy rates. It seems that gentrification in metropolises like London will hunker down in the classically gentrified areas closest to the central business district, but may go into demise in marginal and especially ultra marginal (usually new-build) areas (Lees, 2009). 


\section{NOTES}

(1) This paper is based on the papers given by the authors at the Seminar - New-Build Gentrifications: Form, Places, Processes, University of Neuchatel, Switzerland, November 2007. Mark Davidson presented a paper titled: 'Gentrifying Place: The Coalescence of Urban Policy and New-Build Gentrification'. Loretta Lees presented a keynote address titled: 'New-Build Gentrification: Its Histories and Trajectories'. She also presented other versions of this paper to The Bartlett School research seminar series at University College London (April, 2008) and at The Urban Salon (May, 2008). She would like to thank all these audiences for their useful comments and feedback.

(2) Curran (2007) adds to this literature in her research on industrial displacement in the gentrifying Williamsburg in Brooklyn, New York.

(3) Population ageing, low fertility, the postponement of marriage and childbearing, declining marriage and rising divorce rates, increasing proportions of children born outside wedlock, and growing numbers of households cohabiting or living in non-conventional or 'fluid' household structures (Buzar et al., 2007a).

(4) It will be interesting to see what the impact of the current housing market downturn has on this giant displacement machine.

(5) Better, although still not perfect, Newman and Wyly (2006) used the New York City Housing and Vacancy Survey to quantify displacement in New York City within wider intra-city migration patterns. They found that displacement (due to housing expense, landlord harassment, and private action) ranged between $6.2 \%$ and $9.9 \%$ of renter households.

(6) In 2001, the UK Census replaced the previous social class measure (socio-economic group) with the socio-economic classification (see Rose and O'Reilly, 1998).

(7) Blunt and Dowling (2006: 2-3) argue: 'home is: a place/site, a set of feelings/cultural meanings, and the relations between the two'.

(8) See the 2007 BBC1 documentary The Tower.

(9) On alternatives to the gentrification of Pepys, see Saunders (2009).

\section{REFERENCES}

Allen C. 2008. Housing Market Renewal and Social Class. Routledge: London.

Atkinson R. 2000. The hidden costs of gentrification: displacement in Central London. Journal of Housing and the Built Environment 15: 307-326.
Atkinson R. 2006. Padding the bunker: strategies of middle-class disaffiliation and colonisation in the city. Urban Studies 43: 819-832.

Betancur J. 2002. The politics of gentrification: the case of West Town in Chicago. Urban Affairs Review 37: 780-814.

Blunt A, Dowling R. 2006. Home. Routledge: London.

Boddy M. 2007. Designer neighbourhoods: new-build residential development in nonmetropolitan UK cities - the case of Bristol. Environment and Planning A 39: 86-105.

Bridge G. 2001. Bourdieu, rational action and the timespace strategy of gentrification. Transactions of the Institute of British Geographers 26: 205-216.

Butler T. 2007a. For gentrification? Environment and Planning A 39: 162-181.

Butler T. 2007b. Re-urbanizing London's Docklands: gentrification, suburbanization or new urbanism? International Journal of Urban and Regional Research 31: 759-781.

Butler T with G. Robson. 2003. London Calling: The Middle Classes and the Re-Making of Inner London. Oxford: Berg.

Butler T, Hamnett C, Ramsden M. 2008. Inward and upward? Marking out social class change in London, 1981-2001. Urban Studies 45: 106-124

Buzar S, Hall R, Ogden, PE. 2007. Beyond gentrification: the democratic re-urbanisation of Bologna. Environment and Planning A 39: 64-85.

Cameron S. 2003. Gentrification, housing redifferentiation and urban regeneration: 'Going for Growth' in Newcastle upon Tyne. Urban Studies 40: 23672382.

City of Vancouver. 1991. Downsouth Community Plan. City of Vancouver: Vancouver, BC.

Clark E. 2005. The order and simplicity of gentrification - a political challenge. In Gentrification in a Global Context: The New Urban Colonialism, Atkinson R, Bridge G (eds): London: Routledge: 256-264.

Congdon P. 1989. An analysis of population and social change in London wards in the 1980s. Transactions of the Institute of British Geographers 14: 478-491.

Curran W. 2007. From the frying pan to the oven: gentrification and the experience of industrial displacement in Williamsburg, Brooklyn. Urban Studies 44: 1427-1440.

Davidson M. 2007. Gentrification as global habitat: A process of class construction or corporate creation? Transactions of the Institute of British Geographers 32: 490-506.

Davidson M. 2008. Spoiled mixture: where does stateled 'positive' gentrification end? Urban Studies 45: 2385-2406.

Davidson M. 2009a. London's Blue Ribbon Network: riverside renaissance along the Thames. In Regenerating London: Governance, Sustainability and 
Community in a Global City, Imrie R, Lees L, Raco M (eds): Routledge: London: 173-191.

Davidson M. 2009b. Displacement, space/place and dwelling: placing gentrification debate Ethics, Environment and Place 12: 219-234.

Davidson M, Lees L. 2005. New-build 'gentrification' and London's riverside renaissance. Environment and Planning A 37: 1165-1190.

Freeman L. 2005. Displacement or succession? Residential mobility in gentrifying neighborhoods. Urban Affairs Review 40: 463-491.

Freeman L. 2006. There Goes the 'Hood: Views of Gentrification from the Ground Up. Temple University Press: Philadelphia.

Fried M. 1963. Grieving for a lost home. In The Urban Condition: People and Policy in the Metropolis, Duhl L (ed.): Basic Books: New York; 151-171.

Glass R. 1964. Introduction: Aspects of Change, in Centre for Urban Studies. London: Aspects of Change. MacGibbon and Kee: London.

Haase A, Kabisch S, Steinführer A. 2005. Reurbanisation of inner-city areas in European cities. In Society, Economy, Environment - Towards the Sustainable City, Sagan I, Smith D (eds): Gdansk: Poznan: 75-91.

Haase A, Steinfuhrer A, Kabisch S, Buzar S, Hall R, Ogden P. 2007. Reurbanisation - Just a Variety of Gentrification or a Comeback of City-Mindedness as a Housing Preference? Unpublished conference paper presented to New-Build Gentrification: Forms, Places and Processes, University of Neuchatel, Switzerland.

Hackworth J. 2007. The Neoliberal City: Governance, Ideology and Development in American Urbanism. Cornell University Press: London and Ithaca.

Hackworth J, Smith N. 2001. The changing state of gentrification. Tijdschrift voor Economische en Sociale Geografie 92: 464-477.

Hall R, Ogden P. 2003. The rise of living alone in Inner London: trends among the population of working age, Environment and Planning A 35: 871-888.

Hamnett C. 1994. Social polarization in global cities: theory and evidence. Urban Studies 31: 401-424.

Hamnett C. 2003a. Unequal City: London in the Global Arena, Routledge: London.

Hamnett C. 2003b. Gentrification and the Middle-Class remaking of Inner London, 1961-2001. Urban Studies 40: 2401-2426.

Hamnett C, Whitelegg A. 2007. From industrial to post industrial uses: The loft conversion market in London. Environment and Planning A 39: 106124.

Hartman C. 2002. City for Sale: The Transformation of San Francisco. University of California Press: Berkeley.

Hartman C, Keating D, LeGates R with S. Turner. 1982. Displacement: How to Fight It. National Housing Law Project: Berkeley.
Harvey D. 1989. From managerialism to entrepreneurialism: the transformation of urban governance in late capitalism. Geografiska Annaler 71(B): 3-17.

Harvey, D. 2000. Spaces of Hope. University of California Press: Berkeley.

Lambert C, Boddy M. 2002. Transforming the City: PostRecession Gentrification and Re-Urbanisation. Research Paper 6. ESRC Centre for Neighbourhood Research. [Online] Available at http:/ /www.neighbourhoodcentre.org.uk [accessed 28 July 2005].

Lees L. 2000. A re-appraisal of gentrification: towards a 'geography of gentrification'. Progress in Human Geography 24: 389-408.

Lees L. 2003a. Super-gentrification: the case of Brooklyn Heights, New York City, Urban Studies 40: 24872509.

Lees L. 2003b. Visions of 'Urban Renaissance': the Urban Task Force Report and the Urban White Paper. In Urban Renaissance? New Labour, Community and Urban Policy, Imrie R, Raco M. (eds): Policy Press: Bristol: 61-82.

Lees L. 2008. Gentrification and social mixing: towards an urban renaissance? Urban Studies 45: 2449-2470.

Lees L. 2009. Urban renaissance in an urban recession: the end of gentrification? Environment and Planning A 41: 1529-1533.

Lees L, Demeritt D. 1998. Envisioning the livable city: the interplay of 'Sin City' and 'Sim City' in Vancouver's planning discourse. Urban Geography 19: 332359.

Lees L, Ley D. 2008. Special issue: gentrification and public policy. Urban Studies 45: 2379-2384.

Lees L, Slater T, Wyly E. 2008. Gentrification, Routledge: New York.

Lonsdale S. 2004. Tears of the clown as his tower gets a fancy facelift. Telegraph, 13 November. Available at http:/ / www.telegraph.co.uk [accessed 26 August 2009].

Marcuse P. 1985. Gentrification, abandonment and displacement: connections, causes and policy responses in New York City. Journal of Urban and Contemporary Law 28: 195-240.

Marcuse P. 1986. Abandonment, gentrification, and displacement: the linkages in New York City. In Gentrification of the City, Smith N, Williams P (eds): Allen and Unwin, Boston: 121-152.

McKinnish T, Walsh R, White T. 2008. Who Gentrifies Low Income Neighbourhoods? Center for Economic Studies, US Census Bureau.

Mills C. 1988. 'Life on the upslope': the postmodern landscape of gentrification. Environment and Planning D 6: 169-189.

Mills C. 1989. Interpreting Gentrification: Postindustrial, Postpatriarchal, Postmodern? Unpublished PhD dissertation, Department of Geography, University of British Columbia, Canada. 
Mills C. 1993. Myths and meanings of gentrification. In Place/Culture/Representation, Duncan J, Ley D (eds): London: Routledge: 149-170.

Newman K, Wyly E. 2006. The right to stay put, revisited: gentrification and resistance to displacement in New York City. Urban Studies 43: 23-57.

Oesch D. 2006. Coming to grips with a changing class structure: an analysis of employment stratification in Britain, Germany, Sweden and Switzerland. International Sociology 21: 263-288.

Purnell S. 2002. Yes, this is Brentford! Telegraph, 8 May. Available at http:/ / www.telegraph.co.uk [accessed 28 August 2009].

Relph T. 1977. Humanism, phenomenology, and geography. Annals of the Association of American Geographers 67: 177-183.

Rose D, O'Reilly K. 1998. The ESRC Review of Government Social Classifications. Office for National Statistics: London.

Saunders M. 2009. Bottom up v's top down: Jess from Pepys, a social housing estate in South London. In Whose Urban Renaissance?: An International Comparison of Urban Regeneration Strategies, Porter L, Shaw K (eds): Routledge, London: 234-238.

Shaw C. 2007. Gentrification reality tour: neither benign nor benevolent. Chavan A, Peralta C, Steins C. (eds): Planetizen Contemporary Debates in Urban Planning. Island Press: Washington, DC: 150153.

Shaw K. 2005. Local limits to gentrification: implications for a new urban policy. In Gentrification in a Global Context: The New Urban Colonialism, Atkinson R, Bridge G (eds): Routledge: London: 168-184.

Slater T. 2006. The eviction of critical perspectives from gentrification research, International Journal of Urban and Regional Research 30: 737-757.

Slater T. 2009. Missing Marcuse: on gentrification and displacement. CITY: Analysis of Urban Trends, Culture, Theory, Policy, Action 13: 292-311.
Smith J. 2001. Mixing It Up: Public Housing Redevelopment in Chicago. Paper presented at Area-Based Initiatives in Contemporary Urban Policy Conference, Danish Building and Urban Research/European Urban Research Association, Copenhagen, 17-19 May.

Smith N. 1982. Gentrification and uneven development. Economic Geography 58: 139-155.

Smith N. 1986. Gentrification, the frontier, and the restructuring of urban space. In Gentrification of the City, Smith N, Williams P (eds): Allen \& Unwin: London: 15-34.

Smith N. 1996. The New Urban Frontier: Gentrification and the Revanchist City. Routledge: New York.

Smith N. 2002. New globalism, new urbanism: gentrification as global urban strategy. Antipode 34: 427450.

Smith N. 2008. On 'The Eviction of Critical Perspectives'. International Journal of Urban and Regional Research 32: 195-197.

Tuan Y. 1977. Space and Place: The Perspective of Experience. University of Minnesota Press: Minneapolis.

Wacquant L. 2008. Relocating gentrification: the working class, science and the state in recent urban research. International Journal of Urban and Regional Research 32: 198-205.

Watt P. 2006. Respectability, roughness and 'race': neighbourhood place images and the making of working-class social distinctions in London. International Journal of Urban and Regional Research 30: 776797.

Watt P. 2008. The only class in town? Gentrification and the middle-class colonization of the city and the urban imagination. International Journal of Urban and Regional Research 32: 206-211.

Zukin S. 1991. Landscapes of Power: From Detroit to Disney World. University of California Press: Berkeley. 